\title{
A comparison of pre-service English Language Teacher Training Systems in Turkey and Japan*
}

\author{
Ayşe Yeliz ALDEMİ ${ }^{* *} \quad$ Kemal Oğuz ER ${ }^{* * *}$
}

\begin{abstract}
This is a cross-national comparative education study which aims to define the similarities and differences between English Language Teacher Training Systems in Turkey and Japan. Correlational comparative survey method was used and horizontal approach was preferred. In the study, Higher Education Programs for Pre-Service English Language Teacher Training in Turkey including the entry requirements to these programs, the courses served and the certificate programs were examined. Then, Pre-Service English Language Teacher Training Institutions in Japan were studied within the same categories. The similarities and differences between the English Language Teacher Education Systems in both countries were defined.
\end{abstract}

Keywords: Pre-Service English Language Teacher Training, Japan, Comparative Education.

\footnotetext{
* This study is a summarized version of the M.A. Thesis with the title: "The Comparison of English Language Teacher Training Systems in Turkey and Japan" written by Graduate student Ayşe Yeliz ALDEMIR and supervised by Assist. Prof. Dr. Kemal Oğuz ER at Balıkesir University, Graduate School of Social Sciences.

** Teacher of English, Balıkesir Provincial Directorate of National Education, Balıkesir, Turkey.

*** Assist. Prof. Dr., Balıkesir University, Necatibey Faculty of Education, Balıkesir, Turkey. E-mail:kemaloguzer@hotmail.com
} 


\section{SUMMARY}

Purpose and Significance: The general aim of this study is to define the similarities and differences between Pre-Service English Language Teacher Training Systems in Turkey and Japan. For this purpose, a comparative education study including the two countries was carried out. Comparative Education is a discipline that helps to identify the similarities and differences and explains the facts that appear similar between two or more education systems in different cultures and various countries, and puts forward useful suggestions about the ways to educate people (Türkoğlu, 1985). Thanks to comparative education studies; we can improve ourselves as educators and handle today's educational problems with different perspectives by studying the education systems of different countries and various factors that results in the formation of these systems such as religion, economy, culture and regime.

Methods: In this study, horizontal approach was preferred as PreService English Language Teacher Training Systems in Turkey and Japan were studied. Descriptive approach was chosen as it was aimed to put forward comparisons by defining similarities and differences found by collecting documents.

Results: Candidates who want to be English Language Teachers in Turkey must take the Higher Education Entrance Exam that is the first phase of Central Examination System. In the second phase, they must take the Undergraduate Placement Test which is a Foreign Language Test. In Japan, the exam taken to become an English Language Teacher is the same for the other fields of teaching. English Language Teachers in Turkey are usually the graduates of English Language Teaching Undergraduate Programs opened within the Faculties of Education. In order to meet the teacher deficit, different certificate programs and distance learning opportunities within the Faculty of Open Education are offered. English Language Teaching Undergraduate Programs in Turkey usually last for 4 years but those with preparation class last for 5 years. In Japan, while undergraduate degree is adequate for an English Language Teacher working in junior high school to have a first class certificate, teachers who want to be assigned to high schools must have a graduate degree. Field courses served in English Language Teaching Undergraduate Programs in Turkey and Japan show some similarities. In both countries, the candidates must take General Culture Courses, Field and Field Training Courses and Teaching Profession Courses. At the same time, they must take application courses in the application schools chosen by the faculties. While there is one credit Social 
Volunteering Work in Japan, there is a Community Service Course for the students in Turkey.

Discussion and Conclusions: English Language Teaching Undergraduate Programs for both primary and high schools should be organized as two different programs such as "Primary English Language Teaching" and "High School English Language Teaching". Courses that are appropriate for the developmental levels and needs of the students with whom the teacher candidates work should be given in Primary English Language Teaching Programs. The greater importance given to the courses suitable for children such as "Teaching English to Children" which has already been given in the programs will help candidate teachers deal with fewer problems when they start teaching. Similarly, Advanced Reading, Advanced Writing, Advanced Speaking and Advanced Listening Courses should be emphasized in High School English Language Teaching Programs.

It is not sufficient to choose teacher candidates only with a single exam in Turkey. A spoken test should be given in addition to the central examination. Also, questions testing the candidates' knowledge and skills in their major fields should be added to the Civil Servant Selection Examination which includes tests for General Culture and Teaching Profession Knowledge. In addition to these, the teachers who have their graduate degrees should be given priority in the appointment process in order to improve the qualities of the teachers. 


\title{
Türkiye ve Japonya'da İngilizce Öğretmeni Yetiştirme Sistemlerinin Karşılaştırılması
}

\author{
Ayşe Yeliz ALDEMíR** Kemal Ŏguz ER ****
}

ÖZ. Bu çalışma, Türkiye ve Japonya'daki İngilizce öğretmeni yetiştirme sistemlerini karşılaştırarak sistemler arasındaki benzerlikleri ve farklılıkları ortaya koymayı amaçlayan bir ülkeler arası karşılaştırmalı eğitim çalışmasıdır. Çalışmada yöntem, karşılaştırma türü ilişkisel tarama modeli, karşılaştırmalı eğitim yaklaşımı ise yatay yaklaşımdır. Çalışma kapsamında öncelikle Türkiye'de İngilizce öğretmeni yetiştiren yükseköğretim programları, bu programlara giriş koşulları, okutulan dersler, sertifika programları vb. incelenmiştir. Sonrasında Japonya'daki İngilizce öğretmeni yetiştiren kurumlar da benzer başlıklar altında incelenmiş ve iki ülkenin İngilizce öğretmeni yetiştirme sistemleri arasındaki benzerlik ve farklılıklar ortaya konulmuştur.

Anahtar Sözcükler: İngilizce Öğretmeni Yetiştirme, Japonya, Karşılaştırmalı Eğitim.

\footnotetext{
* Bu çalışma, Yrd. Doç. Dr. Kemal Oğuz ER danışmanlığında Yüksek Lisans Öğrencisi Ayşe Yeliz ALDEMİR tarafindan Balıkesir Üniversitesi Sosyal Bilimler Enstitüsü'nde yapılan "Türkiye ve Japonya'da İngilizce Öğretmeni Yetiştirme Sistemlerinin Karşılaştırılması" adlı Yüksek Lisans tezinin bir kısmından özetlenmiştir.

** İngilizce Öğretmeni, Balıkesir İl Milli Eğitim Müdürlüğü, Balıkesir, Türkiye.

${ }^{* * *}$ Yrd. Doç. Dr., Balıkesir Üniversitesi, Necatibey Eğitim Fakültesi, Balıkesir, Türkiye.

E-posta:kemaloguzer@hotmail.com
} 


\section{GİRIŞ}

Bireyler, farklı sosyal ve kültürel gereksinimler, yeni yaşam tarzları ve farklı alışkanlıklar ile giderek çeşitlenen bir yaşam sürmektedirler (Balay, 2004). $\mathrm{Bu}$ değişimler sonucunda ülkeler arası iletişimin ve etkileşimin daha da ilerlediği bir dünyada, eğitim dünyası oldukça değişmiş birbiriyle bağlantılı ve uyumlu olarak yepyeni bir görünüme kavuşmuştur (Türkoğlu, 1998). Değişimleri takip etmek ve çağın ihtiyaçlarına ayak uydurmak isteyen her toplumun geleceğe yönelik eğitim anlayışını benimsemesi gerekmektedir (Balay, 2004). Bilinmektedir ki; çağdaş uygarlık düzeyine ulaşmak ve gelişmiş ülkelerin standardını yakalamak için sadece iyi planlanmış ekonomik yatırımlar yeterli olmamaktadır, hedeflenen standartların yakalanabilmesi aynı zamanda iyi eğitilmiş bireylerle mümkündür (Gömleksiz, 1999). Bu doğrultuda, eğitim sistemlerinin günümüzdeki mevcut en büyük hedefi, bilgi çağı insanını yetiştirebilmektir (Sağlam ve Kürüm, 2005). Donanımlı, çağa ayak uydurabilen bilgi çağı insanı; mesleki, sosyal ve ekonomik ihtiyaçlarını karşılayacak düzeyde en az bir yabancı dil bilmelidir (Gömleksiz, 1999). Bilimsel ve teknolojik gelişmeleri takip ederek, yapılacak çalışmalarda bizzat yer almak; uluslararası ilişkileri, sosyal, siyasal, ekonomik, eğitim ve kültür alanlarında daha ileri götürmek için tüm ülkelerde yabancı dil bilen insanlara ihtiyaç duyulmaktadır (Tok ve Arıbaş, 2008).

2001 y1lında Avrupa Birliği ve Kültür Genel Müdürlüğü (ABKGM) tarafindan yayınlanan komisyon raporunda, hem kültürel ve sosyal hem de ekonomik olarak Avrupa potansiyelinin gerçekleştirilmesi için daha iyi yabanc1 dil öğretiminin zorunlu olduğu belirtilmiştir (ABKGM, 2001).

Bireylerin gelişimlerinin desteklenmesi ve toplumsal kalkınmanın gerçekleştirilmesinde temel araç kaliteli bir eğitimdir ve eğitimde de kalitenin ön koşulu nitelikli öğretmenlerdir. Bu nedenle, eğitim sistemi içinde görev yapan öğretmenlerin niteliklerini arttırmak ve yetkin öğretmenler yetiştirmek için öğretmen yetiştirme programlarının amaçları ve içerikleri çağa uygun olarak geliştirilmelidir (Adıgüzel, 2005).

Etkin yabancı dil öğretimi ile öğretmen yetiştirme programları arasında doğrudan bir ilişski bulunduğunu öne süren Coşkun (2009), yabancı dil öğretmeni yetiştirme programlarının ülkelerin gereksinimlerine cevap verebilecek nitelikte olması gerektiğini belirtmektedir. Güler (2005) tarafından da ifade edildiği gibi; bilimsel bir zemin üzerine yapılanmış yabanc1 dil öğretmeni yetiştirme programları ile, uzak bir hedef olarak görülmesine rağmen kültürler arası iletişimi başarmak mümkündür. $\mathrm{Bu}$ şekilde oluşacak 'köprüler', hem bireylerin yararına olacak hem de Avrupa Birliği sürecine ve dünya barışına büyük katkılar sağlayacaktır. 
Avrupa Birliği uyum sürecinde çıkabilecek sorunları çözmede ve olası firsatları yakalamada diğer ülkelerin deneyimlerinden yararlanmanın farkında olarak, başka eğitim sistemleri ile Türk Eğitim Sistemi'ni, eğitim ve öğretim programlarını karşılaştırmak faydalı olacaktır. Elde edilen bilgiler, gelişme ve ilerlemelere yardımcı olacak ve eğitim alanında çıkabilecek sorunlara gerekli çözümlerin saptanmasına olanak sağlayacaktır (Tok ve Arıbaş, 2008).

Çalışma dahilinde; birçok açıdan benzer özellikler gösteren Türkiye ve Japonya'da İngilizce öğretmeni yetiştirme sistemleri ile ilgili veriler karşılaştırılmış, benzerlik ve farklılıklar tespit edilmiştir.

\section{Çalışmanın Amacı}

$\mathrm{Bu}$ araştırmanın genel amacı, Türkiye ve Japonya'daki İngilizce öğretmeni yetiştirme sistemlerini karşılaştırarak sistemler arasındaki benzerlik ve farklılıkları ortaya koymaktır. Bu genel çerçevede aşağıdaki sorulara yanit aranacaktır.

1.Türkiye'de uygulanmakta olan İngilizce öğretmeni yetiştirme sistemi nasildir?

2. Japonya'da uygulanmakta olan İngilizce öğretmeni yetiştirme sistemi nasıldır?

3. Türkiye ve Japonya'daki uygulanmakta olan İngilizce öğretmeni yetiştirme sistemleri arasında benzerlikler ve farkl1lıklar nelerdir?

\section{YÖNTEM}

Türkiye ve Japonya'daki İngilizce öğretmeni yetiştirme sistemlerinin karşılaştırıldığ national) karşılaştırmalı eğitim araştırmasıdır.

Karşılaştırmalı eğitim; toplumlarda mevcut eğitim problemlerini ve bu problemleri doğuran nedenleri, diğer toplumlarda benzer faktörlere değinerek saptayan, yorumlayan bir inceleme ve araştırma alanı olarak tanımlamaktadır (Lauwerys, Varış ve Neff, 1971). Karşıllaştırmalı Eğitim araştırmalarıyla, bir ülkedeki eğitim uygulamalarının kökeni ortaya konmaktadır (Erdoğan, 2003).

Karşılaştırma çalışmalarında, yatay ve dikey yaklaşım olmak üzere iki türlü yaklaşımın uygulanmaktadır. Yatay yaklaşımda eğitim sistemlerindeki tüm boyutlar, o döneme ait tüm değişkenlerle birlikte yan yana getirilerek farklılıklar saptanmaya çalışılırken (Ültanır, 2000) dikey yaklaşımda tarihi evrim izlenir (Türkoğlu, 1998). 
Bu çalışmada, Türkiye ve Japonya'daki İngilizce Öğretmeni Yetiştirme Sistemlerinin ele alınması bakımından yatay yaklaşım uygulanmış; dokümanların toplanması, benzerlik ve farklılıkların tanımlanarak karşılaştırılmaların yapılması hedeflendiği için de tanımlayıcı (descriptive) yaklaşım tercih edilmiştir. Çalışma, karşılaştırmalı eğitim çalışması olduğu için karşılaştırma türü ilişkisel tarama modeli tercih edilmiştir. Tarama modeli, Karasar (2008:86) tarafından "geçmişte ya da halen var olan bir durumu var olduğu şekliyle betimlemeyi amaçlayan araştırma yaklaşımı" olarak tanımlanmaktadır. Tarama modelinde; araştırmaya konu olan olay, birey ya da nesne, kendi koşulları içinde ve olduğu gibi tanımlanmaya çalışılmaktadır. Bu amaçla, önce her iki durumun belli değişkenler açısından ayrıntılı betimlemeleri yapılmakta, sonrasında ise ortak ölçütlere göre yapılan bu betimlemeler karşılaştırılmaktadır (Karasar, 2008:86). Bu doğrultuda; çalışmada Türkiye ve Japonya'daki İngilizce öğretmeni yetiştirme sistemleri betimlenmiş ve belirlenen alt problemler doğrultusunda karşılaştırılmıştır.

\section{BULGULAR}

\section{Türkiye'de uygulanmakta olan İngilizce öğretmeni yetiştirme sistemi nasıldır?}

İngilizce öğretiminin ülkemizde giderek önemli hale gelmesinden ve öğretim programlarının önemli bir parçası olmasından dolayı İngilizce öğretmeni açı̆̆ 1 gün geçtikçe artmaktadır. Bu açığı kapatmak için Milli Eğitim Bakanlığı çeşitli yükseköğretim programlarından mezun bireyleri İngilizce öğretmeni olarak atamaktadır (Türker, 2002).

Talim ve Terbiye Kurulu Başkanlı̆̆g'nın (TTKB) 2009 tarih ve 119 sayılı Kurul Kararı kapsamında "Millî Eğitim Bakanlığına Bağlı Eğitim Kurumlarına Öğretmen Olarak Atanacakların Atamalarına Esas Olan Alanlar İle Mezun Oldukları Yükseköğretim Programları ve Aylık Karşılığı Okutacakları Derslere İlişkin Çizelge"de Milli Eğitim Bakanlığı'na (MEB) bağlı eğitim kurumlarına İngilizce öğretmeni olarak atanacakların atamalarına esas olan yükseköğretim programları şu şekilde belirtilmiştir (MEB, 2009b):

1. İngilizce Öğretmenliği

2. İngiliz Dili ve Edebiyatı Bölümü ${ }^{1}$

3. Amerikan Kültürü ve Edebiyatı Bölümü ${ }^{1}$

${ }^{1}$ Bakanlık ve Yüksek Öğretim Kurulu (YÖK) iş birliği ile açılan / açılacak olan Ortaöğretim Alan Öğretmenliği Tezsiz Yüksek Lisans ya da Pedagojik Formasyon Programını başarı ile tamamlayanlar. 


\title{
4. Mütercim-Tercümanlık Bölümü ${ }^{1}$ \\ 5. İngiliz Dil Bilimi Bölümü ${ }^{1}$ \\ 6. Çeviribilimi Bölümü ${ }^{1}$ \\ 7. İngiliz Dili ve Kültürü Bölümü1
}

İngilizce öğretmeninin karşılanamadığı zamanlarda ise İngilizce öğretmeni olarak atanma kriterleri, 2009 tarih ve 2617 sayılı Tebliğler Dergisi'nde yayımlanan "Millî Eğitim Bakanlığına Bağlı Eğitim Kurumlarına Öğretmen Olarak Atanacakların Atamalarına Esas Olan Alanlar İle Mezun Oldukları Yükseköğretim Programları ve Aylık Karşılığı Okutacakları Derslere İlişkin Esaslar" kapsamında yer alan Ek Çizelge'de belirlenmiştir (MEB, 2009b).

\begin{abstract}
İngilizce öğretmen açığının, İngilizce öğretmenliğine kaynak olarak belirlenen ek çizelgedeki yükseköğretim programlarından mezun olanlar ile karşılanamadığ 1 durumlarda, bu dersin öğretmenliğine, yabancı dille öğretim yapan yükseköğretim programlarından mezun olup İngilizce Öğretmenliği Sertifikası Programını bitirenler ile Eğitim Fakülteleri, Fen Fakülteleri, Edebiyat Fakülteleri ve Fen-Edebiyat Fakültelerinin alan öğretmenliği bölümlerinden mezun olup "Kamu Personeli Yabancı Dil Bilgisi Seviye Tespit Sinavı (KPDS)"nda (B) ve daha yukarı düzeyde puan alanlardan İngilizce Öğretmenliği Sertifikası Programını bitirenler atanırlar. Yabancı Dil, Rehberlik ve Psikolojik Danışmanlık, Bilgisayar, Resim İş/Resim, Müzik ve Beden Eğitimi alanları, ilköğretim ve orta ögretimde ortak alanlardır (MEB, 2009b, Madde 7).
\end{abstract}

Öğretmen adaylarının seçimi için ülke çapında uygulanmakta olan Öğrenci Seçme Sınavı, 2009 yılı itibari ile "Yükseköğretime Giriş Sınavı" olarak değiştirilmiştir. $\mathrm{Bu}$ nedenle yukarıda bahsi geçen ve Anadolu Üniversitesi Açık Öğretim Fakültesi’nde açılan İngilizce Öğretmenliği Lisans Programı için belirlenen taban puanlar ve diğer kriterler, 2010 y1lında yeni sisteme uyarlanmıştır.

2009 y1lı itibari ile uygulanmaya başlanan Yükseköğretime Geçiş Sınavı (YGS) kapsamında Yabancı Dil alanlarında bir yükseköğretim programına yerleşmek ya da İngilizce Öğretmeni olmak isteyen adaylar Merkezi Sınav Sisteminin Birinci Aşaması olan Yükseköğretime Geçiş Sınavına (YGS) girmesi ve en az 180 puan almalıdırlar. İkinci Aşama olan Lisans Yerleştirme Sınavları'ndan (LYS) ise Yabancı Dil Sınavı'nı (LYS-5) başarı ile geçmeleri gerekmektedir. Yabancı Dil Sınavı (LYS-5) tek oturumda uygulanan ve toplam 120 dakika süren bir sinav olup adaylara 80 soru sorulmaktadır. Yabancı Dil Sinavı Almanca, Fransızca ve İngilizce olmak üzere üç dilde yapılmaktadır. Bu testlerde kelime bilgisi ve dil bilgisi, Türkçeden yabancı dile, yabancı dilden Türkçeye çeviri ve okuduğunu anlama ile ilgili sorular bulunmaktadır (ÖSYM, 2010). Sınav sonucunda üç 
türlü sınav puanı oluşturulmaktadır, puan türleri için diğer genel kültür testlerinin ağıllıkları değişiklik göstermektedir (Çizelge 1).

Çizelge 1. Yabancı Dil Puan Türleri İçin Girilecek Sınavlar ve Testlerin Ağırlıkları

\begin{tabular}{|c|c|c|c|c|c|}
\hline \multirow[b]{3}{*}{ Puan Türü } & \multicolumn{5}{|c|}{ Testlerin Ağırlıkları (\%) } \\
\hline & \multicolumn{4}{|c|}{ YGS } & \multirow{2}{*}{$\begin{array}{c}\text { LYS } \\
\text { Yabancı } \\
\text { Dil }\end{array}$} \\
\hline & Türkçe & $\begin{array}{c}\text { Sosyal } \\
\text { Bilimler }\end{array}$ & $\begin{array}{c}\text { Temel } \\
\text { Matematik }\end{array}$ & $\begin{array}{c}\text { Fen } \\
\text { Bilimleri }\end{array}$ & \\
\hline DİL-1 & 15 & 9 & 6 & 5 & 65 \\
\hline DİL-2 & 25 & 13 & 7 & 5 & 50 \\
\hline DİL-3 & 48 & 20 & 7 & 5 & 20 \\
\hline
\end{tabular}

2010 y1lında uygulanmaya başlanan yeni sistem ile önceden tek olan yabancı dil puanı 3 türe ayrılmıs ve hangi lisans programının hangi program ile öğrenci alacağ 1 yeniden belirlenmiştir (ÖSYM, 2010). Bu yeni puan türlerine göre; İngilizce Öğretmenliği Lisans Programlarını tercih edecek adayların, DİL-1 puanını kullanmas1 gerekmektedir. DİL-1 puanının hesaplanmasında ögrencilerin sorumlu oldukları dersler ve bu derslere ilişkin testlerin ağırlıkları Çizelge 1'de gösterilmektedir. Testlerin ağırlıklarına bakıldığında; Yabancı Dil Testi'nin \%65, Türkçe Testi'nin \%15, Sosyal Bilimler Testi'nin \%9, Temel Matematik Testi'nin \%6 ve Fen Bilimleri Testi'nin ise $\% 5$ ağırlıklı olduğu görülmektedir. Adaylar, tercihlerine ve puan üstünlüğü esasına göre sıralama yapılarak Öğrenci Seçme ve Yerleştirme Merkezi (ÖSYM) tarafindan lisans programlarına yerleştirilmektedirler.

\section{İngilizce Öğretmenliği Lisans Programı}

Bir öğretim kurumunda İngilizce öğretmeni olarak çalışabilmek için Eğitim Fakültelerinin İngilizce Öğretmenliği Lisans Programı mezunu olmak gerekmektedir (Yıldız Teknik Üniversitesi [YTÜ], 2009).

İngilizce Öğretmenliği Lisans Programı kapsamında öğrenim gören yükseköğretim öğrencileri, 143 saat teorik, 32 saat uygulamalı olmak üzere 175 saat lisans dersi görerek, toplamda 159 krediyi tamamlamaktadırlar (YÖK, 2009).

Türkiye'de 8 yıllık kesintisiz zorunlu eğitimin uygulanması ve Yabancı Dil olarak İngilizce derslerinin 4. siniflardan itibaren zorunlu ders olarak okutulmasından dolayı İngilizce öğretmenlerine yönelik yoğun talep, sadece 
İngilizce Öğretmenliği Lisans Programı'ndan mezun olan öğretmen adayları ile karşılanamamaktadır.

Türkiye'nin en önemli sorunlarından biri, öğretmen açı̆̆ olup özellikle İngilizce öğretmeni eğitimi ve mevcut sistemdeki İngilizce öğretmeni ihtiyacı üzerinde durulması gereken hassas bir konudur (Türker, 2002).

4 Mayıs 2010 tarihli MEBBİS Norm İşlemleri Modülü verilerine göre, bakanlığa bağlı resmi eğitim kurumlarının 78 bin 321 öğretmen ihtiyacı bulunmaktadır. En fazla öğretmen ihtiyacı, 24 bin 331 öğretmen ile rehber öğretmenlik alanında bulunmaktadır. Rehber öğretmen açı̆̆ını İngilizce, sınıf öğretmeni, din kültürü ve ahlak bilgisi, bilişim teknolojileri öğretmeni açığı takip etmektedir. İngilizce alanında 11 bin 874, sınıf öğretmenliğinde 11 bin 221, din kültürü ve ahlak bilgisi öğretmenliğinde 11 bin 101, bilişim teknolojileri alanında ise 10 bin 100 öğretmen açığı bulunmaktadır (Milliyet, 2010).

Türkiye'de İngilizce öğretmeni açığını kapatmak için Anadolu Üniversitesi İngilizce Öğretmenliği Lisans Programı (İÖLP) ve İngilizce Öğretmenliği Sertifika Programı yürütülmektedir.

\section{Anadolu Üniversitesi, İngilizce Öğretmenliği Lisans Programı}

Milli Eğitim Bakanlığı ile Anadolu Üniversitesi Rektörlüğü iş birliğinde hazırlanan İngilizce Öğretmeni Yetiştirme Projesi kapsamında 28/02/2000 tarihinde imzalanan protokolle uygulamaya konan İngilizce Öğretmenliği Lisans Programı (İÖLP), Eğitim Fakültelerinde uygulanmakta olan örgün İngilizce Öğretmenliği Lisans Programlarına eşdeğer dört yıllık bir lisans programıdır (MEB, 2009a; Anadolu Üniversitesi, 2009a).

İÖLP'nin ilk iki yılı kısmen örgün (yüz yüze öğretim) son iki yılı ise tamamen uzaktan öğretim sistemi ile yapılmaktadır. AÖF İÖLP'nin bu son iki y1lı, uzaktan eğitim sistemine uygun olarak ders materyalleri ve internet üzerinden çevrimiçi derslerle desteklenmektedir. "Topluma Hizmet Uygulamaları" ile "Okul Deneyimi ve Öğretmenlik Uygulaması" derslerini, öğrenciler ikamet ettikleri ilde yürütebilmektedirler. Uygulama derslerinin yürütüleceği il öğrenci tarafından fakültelerce ilan edilen tarihler arasında belirlenmelidir. Her iki ders için uygulamalar tek bir il merkezinde yapılmaktadır (Anadolu Üniversitesi, 2009b). 


\section{İngilizce Öğretmenliği Sertifika Programı}

Türkiye'deki ilk ve orta dereceli (devlet ve özel) öğretim kurumlarında ve özel dil dershanelerindeki İngilizce öğretmeni açığını kapatmak amacıyla T.C. Milli Eğitim Bakanlığı ve T.C. Yükseköğretim Kurulu işbirliği ile İngilizce Öğretmenliği Sertifika Programı uygulaması başlatılmıştır (Yıldız Teknik Üniversitesi [YTÜ], 2009). Bu program ile yabancı dil ile eğitim yapan üniversitelerde okuyanlara veya mezunlarına ilköğretim ve ortaöğretim kurumlarında yabancı dil dersi ders verme olanağı sağlamak amaçlanmıştır. Programa; Milli Eğitim Bakanlığı Talim ve Terbiye Kurulu Başkanlı̆̆ı'nın 80 sayılı Kararı eki çizelgede yer alan İngilizce Öğretmenliğine kaynak olarak gösterilen İngiliz Dili ve Edebiyatı, Amerikan Kültürü ve Edebiyatı, Mütercim-Tercümanlık, İngiliz Dil Bilimi, Çeviribilim (İngilizce), İngiliz Dili ve Kültürü programlarının öğrenci ve mezunları başvurabilmektedirler (YTÜ, 2010). Uygulanmakta olan İngilizce Öğretmenliği Sertifika Programı'nda yer alan dersler Çizelge 2'de sunulmuştur.

Çizelge 2. Ingilizce Öğretmenliği Sertifika Programı

\begin{tabular}{ll}
\hline Ders & Kredi \\
\hline I. DÖNEM & $\mathrm{T}-\mathrm{U}-\mathrm{K}$ \\
\hline 1- Eğitim Bilimine Giriş & $2-0-2$ \\
2- Gelişim Psikolojisi & $2-0-2$ \\
3- Program Geliştirme ve Öğretim & $2-0-2$ \\
4- Ölçme ve Değerlendirme & $2-0-2$ \\
5- Dilbilim & $2-0-2$ \\
6- İngilizce Özel Öğretim Yöntemleri & $3-2-4$ \\
I. DÖNEM TOPLAM & $13-2-14$ \\
\hline II. DÖNEM & $\mathrm{T}-\mathrm{U}-\mathrm{K}$ \\
\hline 7- Dilbilgisi Öğretimi & $2-0-2$ \\
8- İngilizce Öğretim Teknolojileri ve & $2-2-3$ \\
9- Öğrenme Öğretme Kuram ve & $2-0-2$ \\
10- Türk Ĕ̆itim Sistemi ve Okul Yönetimi & $2-2-3$ \\
11- Rehberlik & $2-0-2$ \\
12- Öğretmenlik Uygulaması & $2-6-5$ \\
II. DÖNEM TOPLAM & $12-10-17$ \\
\hline TOPLAM & $\mathbf{2 5 - 1 2 - 3 1}$ \\
\hline
\end{tabular}

Kaynak: Yıldız Teknik Üniversitesi. (2009). Ingilizce Öğretmenliğ Sertifika Programı. Web: http://www.yde.yildiz.edu.tr/intro-stf.htm adresinden $28.08 .2009^{`}$ da alınmıştır. 
İngilizce Öğretmenliği Sertifika Programı'ndaki derslerin bulunduğu çizelgede derslerin karşısındaki sütunda gösterilen ilk rakamlar teorik saatleri, ikinci rakamlar uygulama saatlerini, son rakamlar da kredi sayılarını belirtmektedir. Her teorik saat bir krediye ve yine her iki uygulama saati bir krediye eş değerdir. Üniversitelerin lisans programlarından mezun olanlardan, daha önce öğretmenlik sertifikasını almış olanlar, İngilizce Öğretmenliği Sertifika Programı'nda yer alan “Öğretmenlik Mesleğine Giriş" "Gelişim ve Öğrenme" ile "Öğretimde Planlama ve Değerlendirme, derslerinden muaf tutulmaktadırlar. Lisans öğrenimi esnasında bu programa başvuran öğretmen adaylarının, İngilizce öğretmenliği sertifikasına hak kazanabilmeleri için hem sertifika programının derslerini başarıyla tamamlamaları hem de ası kaydını yaptırdıkları lisans programının derslerini başarıyla tamamlamaları gerekmektedir (Can, 2005).

İngilizce öğretmeni olmak isteyenler aynı zamanda tezsiz yüksek lisans uygulaması ile İngilizce öğretmenliği yapabilmektedir. Ortaöğretim Alan Öğretmenliği Tezsiz Yüksek Lisans Programları (4+1.5) 22 Mayıs 2008 tarihli Yükseköğretim Genel Kurul Toplantısında görüşülmüş ve Lisansüstü Eğitim-Öğretim Enstitülerinin Teşkilat ve İşleyiş Yönetmeliği'nin 4. maddesi uyarınca, söz konusu programlara ait derslerin ders içeriklerinin aynı kalarak iki yarıyıl (4+1) olarak kabulü uygun görülmüştür (YÖK, 2008). 2010 yılı itibari ile eğitim fakültesi dışındaki öğrencilerin öğretmen olmak için mezuniyetten sonra aldıkları 'tezsiz yüksek lisans' eğitimi YÖK Genel Kurulu tarafından kaldırılmış, yerine pedagojik formasyon eğitimi getirilmiştir. Ortaöğretim alan öğretmenliği tezsiz yüksek lisans eğitimleri 2010-2011 eğitim-öğretim yılından itibaren açılmayacak ve daha önce izin verilenlere öğrenci alınmayacaktır. Bu öğretim yılından itibaren mezun durumda olan öğrencilere de pedagojik formasyon sertifikası eğitimi verilmeye başlanacaktır. Formasyon eğitimi, 5. yarıyılda başlayacak ve 2 yıla (dört yarıyıla) yayılarak verilecektir. Formasyon eğitimine kabul edilebilmeleri için öğrencilerin ağırlıklı not ortalamasının 4 üzerinden en az 2,5 olması ve en fazla alttan başarısız 2 dersinin olması gerecektir. Mezun durumda olan öğrencilerin de diploma notu 4 üzerinden en az 2,5 olacak ve mezunların formasyon eğitimi süresi iki yarıyıla (1 yıl) yayılacaktır (Asalığlu, 2010; Atakan, 2010).

\section{Japonya'da İngilizce Öğretmeni Yetiştirme nasıldır?}

Japonya'da İngilizce Öğretmenliği Sertifikası alabilmek için öğretmen adayları bazı gereklilikleri karşılamak zorundadır. Japonya'da gerekli olan dersler sürekli değişim geçirmektedir. En büyük değişim Nisan 1999'da olmuş ve konu alanı derslerinin sayısı azaltılarak pedagoji ve psikoloji 
derslerine ağırlık verilmiştir (Çizelge 3). Sosyal gönüllülük çalışması da ortaokul dersleri kapsamında zorunlu ders olarak belirlenmiştir (Yonesaka, 1999).

Çizelge 3'te belirtilen "Alan" kavramı, öğrencilerin sahip olmaları gereken nitelikleri ve lisans eğitimleri sırasında tamamlamaları gereken ders türleri ile kredi sayılarını içermektedir.

Çizelge 3. Ortaokul ve Lise Ingilizce Öğretmenleri için Birinci Sınıf Sertifika Gereklilikleri

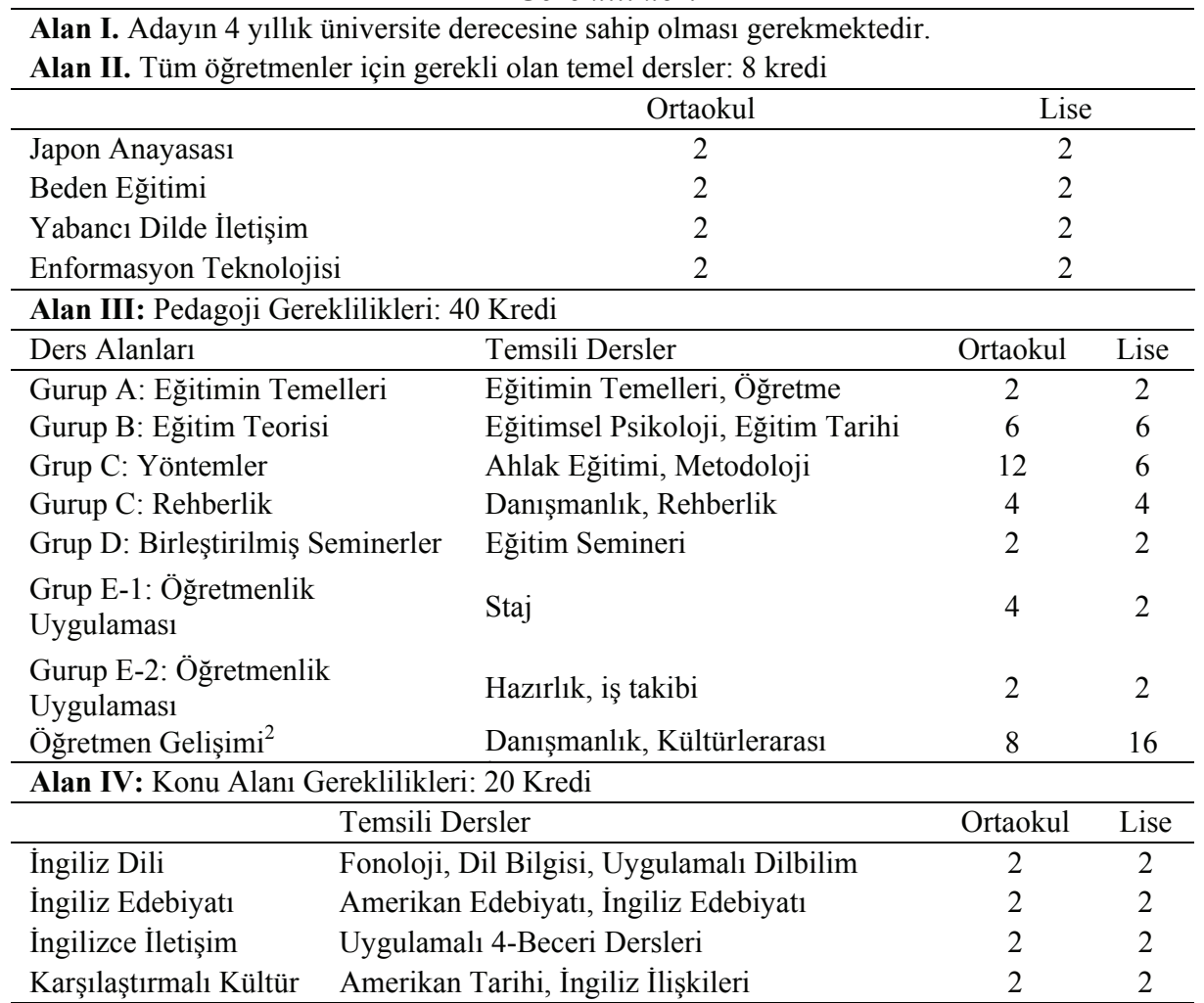

Alan V: Sadece ortaokul öğretmenleri için: 1 kredi Sosyal Gönüllülük Çalışması Alanında Staj: Adayın gönüllü işi sürdürdükleri kurumdan, stajın tamamlandığına dair bir sertifika almasi gerekmektedir

Kaynak: Yonesaka, S. (1999). The Pre-service Training of Japanese Teachers of English. The Language Teacher Online: Issue 23.11; November 1999. Web: http://www.jaltpublications.org/tlt/articles/1999/11/yonesaka adresinden 06.05.2010'da alınmıştır.

${ }^{2}$ Üniversiteler bu alanı tamamlamak için pedagoji ya da konu alanı derslerini seçebilirler, fakat danışmanlık alanında en az bir dersin dahil edilmesi Eğitim Bakanlığı tarafından önerilmektedir. 
Çizelge 3’te de görüldüğü üzere, Japonya'da İngilizce öğretmeni olabilmek için adayların, diğer branşlarda olduğu gibi 4 yıllık lisans mezunu olmaları gerekmektedir. Lisans eğitimleri sırasında öğrenciler; Genel Kültür Derslerini, Pedagoji (Öğretmenlik Meslek Bilgisi) Derslerini ve Alan Derslerini tamamlamak zorundadır. Ortaokullarda görev yapacak öğretmenlerin, bu derslere ek olarak, 1 kredilik Sosyal Gönüllülük Çalışması Alanında Stajlarını da başarıyla bitirmeleri beklenmektedir.

Japonya'da İngilizce öğretebilmek için gerekli olan sertifika türü tamamıyla hangi tür öğretim kademesinde eğitim verileceğine bağlıdır. Diğer ülkelerde tüm öğretmenlerin İngilizce eğitimi vermek için TEFL ya da diğer İngilizce Öğretimi Sertifikalarına sahip olması gerekirken Japonya bunu önkoşul olarak sunmamaktadır ve şu anda diğer sanayi ülkelerine nazaran en fazla sertifikasız öğretmenin bulunduğu ülke Japonya'dır. Genel olarak Japonya'daki öğretmenlik türleri incelendiğinde "lise öğretmeni", “üniversite öğretmeni”, "iletişim okulu öğretmeni" ve "iş İngilizcesi öğretmeni" olmak üzere 4 temel İngilizce öğretmenliği türü göze çarpmaktadır. Üniversite ve lise öğretmenleri devlet ve özel kurumlarda çalışırlarken, İletişim okulu öğretmenleri, tüm yaş gruplarına açık olan İletişim okullarında genellikle iletişimsel İngilizce üzerine ders vermektedirler. Benzer bir biçimde, İş İngilizcesi öğretmenleri de birçok kurum tarafından kendi çalışanlarına denizaşırı ülkelerden gelen yatırımcılar ve danışmanlarla iletişim kurabilmelerini sağlayacak temel düzey İngilizce dersleri sunmaktadırlar (Simmons, 2010).

Diğer tüm branş ve sınıf öğretmenlerinde olduğu gibi, İngilizce öğretmeni olarak atanabilmek için, sertifika sahibi mezun bir öğretmen adayının aynı zamanda İl Eğitim Kurulu ya da Belediye Eğitim Kurullarınca yapılan atama sınavlarını da başarıyla geçmesi gerekmektedir. Çoğu kez, öğretmenliğe atanandan çok daha fazla mezun sertifika almaktadır. Yoğun talebe karşılık, sınırlı sayıda kontenjan olması, bu sınavları zorlaştırmaktadır. Yapılan sınavlar, performanstan ziyade teorik bilgiyi ölçmektedir (Kitao, Kitao, Nozawa ve Masayo, 1994).

Japonya'da İngilizce öğretiminin niteliklerini arttırmak, özellikle anadili İngilizce olan öğretmenlerin, okullardaki İngilizce öğretimi alanında gelişmelere yardımcı olmaları amacıyla "Jet Programı" uygulanmaya başlanmıştır. Bireylerin İngilizce öğrenme talebi arttıkça, anadili İngilizce olan yabancilara da daha fazla ihtiyaç duyulmaktadır. Bu gereksinimi karşılayabilmek için İngilizceyi anadili olarak konuşan kişiler Japon üniversitelerinde, şirketlerde ya da yabancı dil okullarında kısmi zamanlı eğitmen olarak görev almaya başlamışlardır (Shishin, 2002). Bu girişim Bakanlık tarafından da destek görmekte ve teşvik edilmektedir. Japonya'da öğrencilerin yabancı dil yeterliliklerine sahip olabilmeleri amacıyla, başka 
ülkelerde öğrenim görmüş ve öğretmenlik deneyimine sahip Yabancı Dil ögretmenlerinin uluslararası adı JET (The Japan Exchange and Teaching) olan Japon Değişim ve Öğretim Programı ile ortaokul ve liselerde görev yapmalarına olanak tanınmıştır.

$\mathrm{Bu}$ program kapsamında; İç İşleri ve İletişim Bakanlığı, Dış İşleri Bakanlığı, Eğitim, Kültür, Spor, Bilim ve Teknoloji Bakanlığı, Uluslararası İlişkiler Yerel Yönetimler Konseyi ile işbirliği dahilinde yerel yönetimler tarafindan yönetilmektedir. 1987 yılında Japonların diğer uluslara mensup kişiler ile aralarındaki ortak anlayışın arttırılması amacıyla başlatılan bu program, Japonya'da yabancı dil eğitiminin gelişmesini sağlamayı ve toplum düzeyinde uluslararası değişimleri geliştirerek Japon Yerel Yönetimlerde uluslararas1 standartların yakalanması hedeflemektedir (Council of Local Authorities for International Relations, 2009). Japon Eğitim, Kültür, Spor, Bilim ve Teknoloji Bakanlığı (MEXT) tarafından görevlendirilen Asistan Dil Öğretmenleri yardımıyla, öğrenciler İngilizce bilgilerini ilerletmek için yüksek düzeyde motivasyona sahip olmakta ve İngilizceyi anadili olarak konuşan kişilerle iletişim kurma şansına sahip olmaktadırlar (Mantero ve Iwai, 2005).

Japonya'da merkezi standart bir öğretim programı olmadığından ve her üniversitenin kendi lisans öğretim programlarını oluşturabileceğinden, öğretim programları farklılık göstermektedir. Çalışma kapsamında Aoyama Gakuin Üniversitesi Lisans Programı ele alınmıştır. Belirlenen standartlar "Aoyama Standardı" Aoyama Gakuin Üniversitesinde öğrenim gören bütün ögrenciler için ortak öğretim programı olup, bütün okul ve bölümlerde görev yapan tüm fakülte üyeleri tarafindan ortaya konulan yeni bir perspektif ile geliştirilmiştir" (Aoyama Gakuin Üniversitesi, 2010a).

Aoyama Gakuin Üniversitesi İngilizce Öğretmenliği Lisans Programı, Çizelge 4'te sunulmuştur. 
Çizelge 4. Aoyama Gakuin Üniversitesi İngilizce Öğretmenliği Lisans Programı

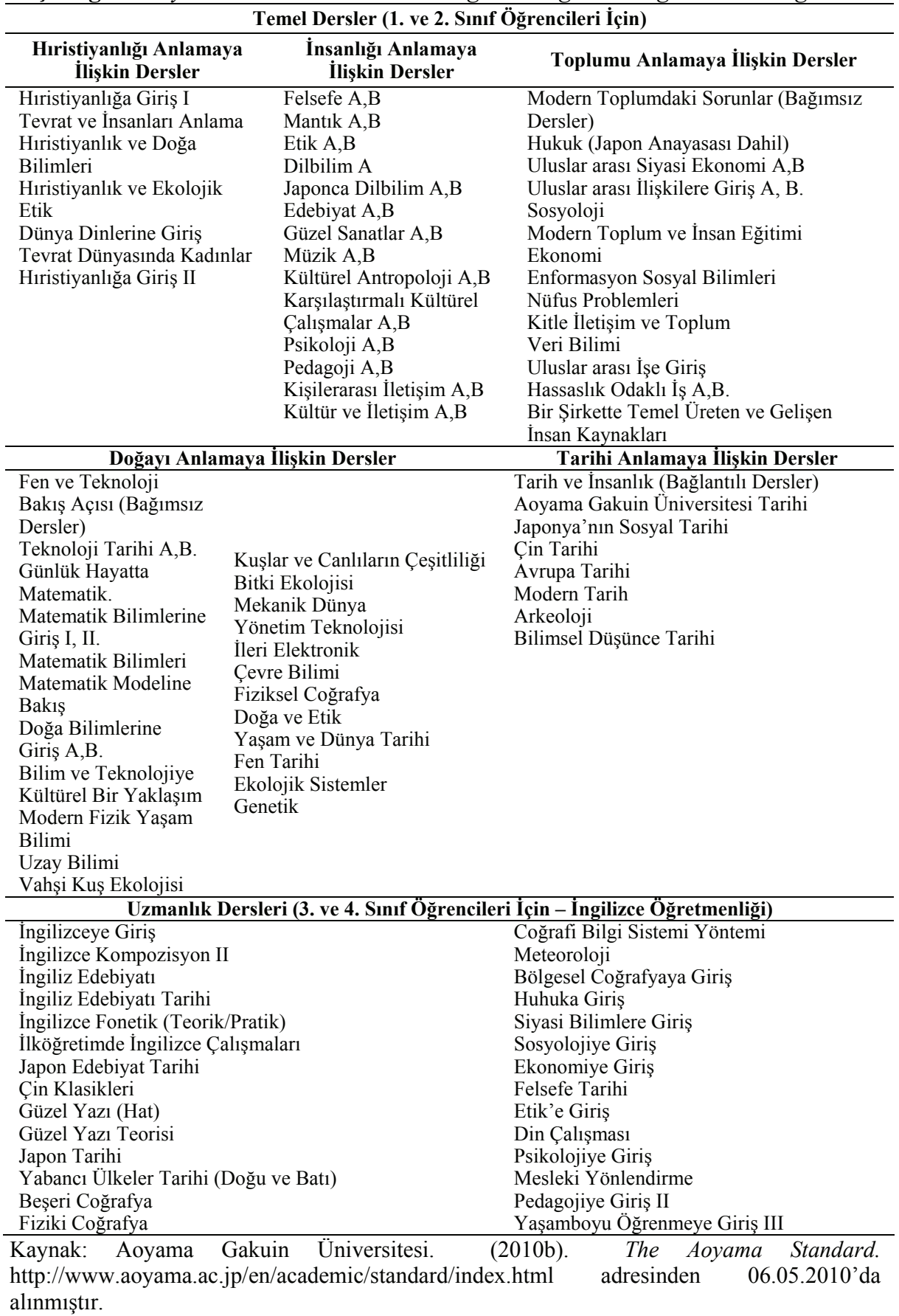


Temel dersler olarak, öğrenciler Hristiyanlık, Okulun Temelleri, İnsanlık Kültürü, Toplum, Doğa ve Tarihi öğrenmektedirler. 1. ve 2. sınıfta verilen temel derslerden sonra öğrenciler 3. ve 4. sinıflarda uzmanlık alan derslerini almaktadırlar. Çizelge 4'te Aoyama Gakuin Üniversitesi İngilizce Öğretmenliği Lisans Programı'nda yer alan temel dersler ve uzmanlık alan dersleri yer almaktadır. Öğrenciler ilk iki yılında belirtilen dersleri aldıktan sonra Eğitim, Psikoloji ve Beşeri Bilimler Fakültesi'nde verilmekte olan kendi alanlarıyla ilgili dersleri almaktadırlar. 3. ve 4. yılları için öğrencilere sunulan uzmanlık derslerinden istenilen minimum krediyi tamamlamaktadirlar.

Aoyama Gakuin Üniversitesi Standart Dersleri, tüm okulda uygulanmakta olan evrensel eğitim sisteminin bir parçası olarak öğrencilere farklı alanlardan ders alma imkânı sunmaktadır. Bu dersler kapsamında Yabanc1 Dil alanında 1. Yıl İngilizce Okuma I ve Sözlü İngilizce I dersleri, İkinci Y1l ise İngilizce Okuma II, Sözlü İngilizce II ve İngilizce Kompozisyon I dersleri sunulmaktadır. Seçmeli dersler olarak ise bu 4 yılda, öğrenciler bölüm derslerinden, Aoyama Standart Derslerinden, Yabancı Dil Seçmeli Derslerinden, Psikoloji Bölümündeki derslerden ve diğer fakültelerde verilmekte olan derslerden minimum kredi sayısını tamamlayabilecek şekilde seçim yapabilmektedirler (AGÜ, 2010b).

Diğer bir örneklem ise Iwate Üniversitesi İngiliz Dili Eğitimi Bölümü Lisans Programı'dır. İngilizce Öğretmenliği alan derslerine örnek teşkil etmesi amaciyla, Çizelge 5'te Iwate Üniversitesi, Eğitim Fakültesi, İngilizce Öğretmenliği Lisans Programları'nda yer alan İngilizce Öğretmenliği Alan Dersleri sunulmuştur.

Genel olarak belirtmek gerekirse; Japonya'da diğer dünya ülkelerinde olduğu gibi, Genel Kültür, Alan Bilgisi ve Meslek Bilgisi boyutlarında eğitim verilmektedir. Dersler seminer ve konferanslar şeklinde olup, genel kültür dersleri ilk 1.5 yıl, Alan ve Meslek dersleri ise kalan 2 veya 2.5 yılda sunulmaktadır. Öğrenciler 36 kredilik Genel Kültür dersleri, 8 kredilik Yabanc1 Dil ile 4 kredilik Beden Eğitimi ve toplamda 48 kredilik ders almaktadırlar. Ortaokullarda 2. sınıf sertifika ile öğretmenlik yapabilmek için, en az 2 yıllık ön lisans eğitimi ve 62 kredilik ders alınması gerekli iken Ortaokul ve Lise 1. Sınıf Öğretmenlik Sertifikası için 4 yıllık üniversite eğitimi ve 124 kredilik ders almak zorunludur (Meriç ve Tezcan, 2005).

Türkiye'de kesintisiz 8 yıllık zorunlu eğitimin uygulanmaya başlaması ve İngilizce derslerinin ilköğretim okullarının dördüncü sınıfından itibaren zorunlu hale getirilmesi ile İngilizce öğretmeni açığı baş göstermiştir. İlköğretim dördüncü sinıftan itibaren İngilizce öğrenmeye başlayan öğrenciler, lise ve üniversitede de İngilizce eğitimlerine devam etmektedirler. Türkiye'den farklı olarak, Japonya'da öğrenciler, ortaokulda 
Yabanc1 Dil (genellikle İngilizce) öğrenmeye başlarlar. Bu doğrultuda, Türkiye'deki öğrencilerin, Japonya'daki akranlarına göre daha erken yaşlarda İngilizce öğrenmeye başladığı söylenebilir.

Çizelge 5. Iwate Üniversitesi İniliz Dili Eğitimi Bölümü Lisans Programı Alan Dersleri

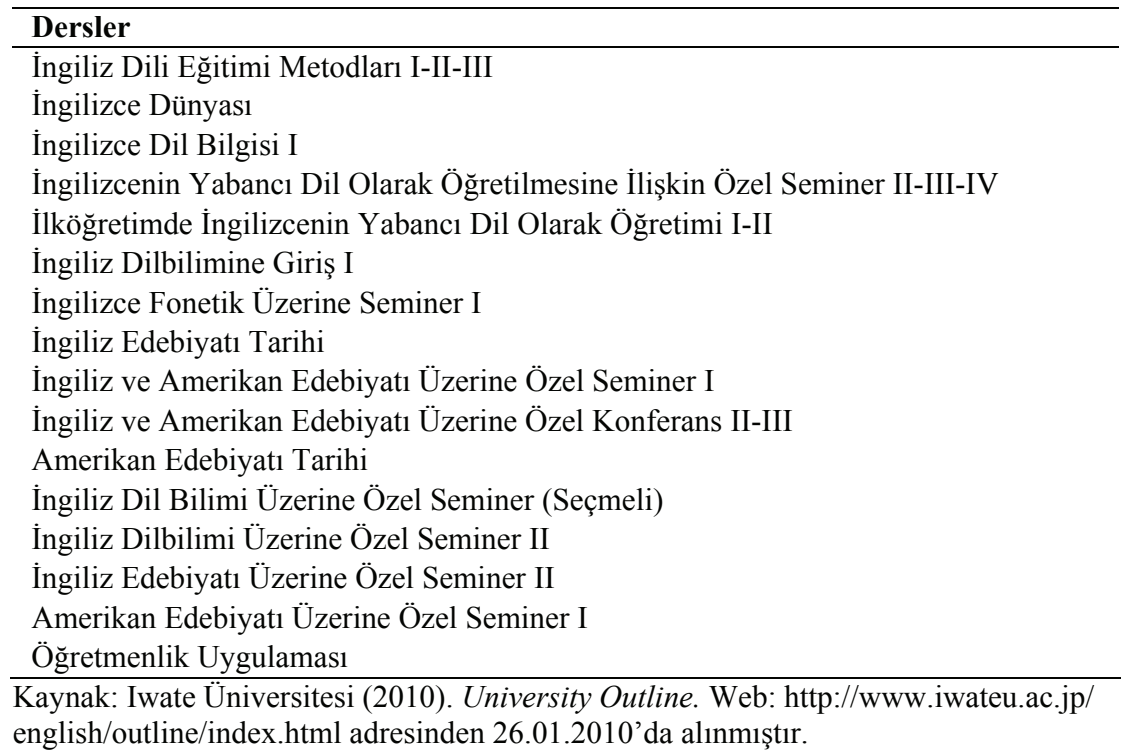

\section{Türkiye ve Japonya'da İngilizce ögrretmeni yetiştirme sistemleri} arasindaki benzerlikler ve farkllliklar nelerdir?

Türkiye'de İngilizce Öğretmenliği Lisans Programları'na yerleşmek isteyen adayların, Merkezi Sınav Sistemi'nin birinci aşaması olan Yükseköğretime Geçiş Sınavı'na (YGS) ve ikinci aşamada ise Lisans Yerleştirme Sınavı'na (LYS-5) girmeleri gerekmektedir. LYS-5, Yabancı Dil Sınavı olup, adaylara Almanca, Fransızca ve İngilizce olmak üzere üç dilde 80 soru sorulmaktadır. İngilizce öğretmenliği programlarına kaydolabilmek için adayların İngilizce sorularını yanıtlayarak, belirli bir puan barajını aşmaları gerekmektedir. Öğretmen açığının kapatılabilmesi amacıyla, İngiliz Dili ve Edebiyatı, Amerikan Kültürü ve Edebiyat1, Mütercim-Tercümanlık, İngiliz Dilbilimi, Çeviribilim, İngiliz Dili ve Kültürü Bölümü gibi bölümlerden mezun olan adaylar da öğretmenlik formasyonu alarak, İngilizce öğretmeni olarak devlet kurumlarında öğretmen olmaya hak kazanmaktadırlar. Bu bölümlere ek olarak, Açık Öğretim Fakültesi bünyesinde de İngilizce Öğretmenliği Lisans programından ve yabanc1 dille eğitim veren diğer üniversitelerden mezun olan bireyler, 
belirlenen kredileri tamamlamaları koşuluyla İngilizce öğretmeni olabilmektedirler.

Japonya'da ise ortaokul ve liselere İngilizce öğretmeni olabilmek için; öğretmen adaylarının, en az 4 yıllık lisans derecesine sahip olmaları ve diğer öğretmenler gibi hem merkezi sinava hem de mülakatlara girmeleri gerekmektedir. Lise öğretmenlerinin birinci sınıf sertifikaya sahip olabilmeleri için yüksek lisans derecesine sahip olmaları gerekmektedir. Türkiye'de ise tüm İngilizce öğretmenlerinin en az 4 y1llık lisans eğitimlerini tamamlamış olmaları esastır. Adayların bir yükseköğretim programından mezun olmaları tek başına yeterli olmamakta ve diğer öğretmenler gibi Kamu Personeli Seçme Sınavı'na girerek istenilen puanı almaları gerekmektedir fakat mülakata tabi değildir.

Türkiye'de İngilizce Öğretmenliği Programları genellikle 4 yıldır. Hazırlık sınıfı olan bölümlerde ise 5 yıl sürer. Japonya'da ise ortaokulda görev yapan İngilizce öğretmenlerinin birinci sınıf sertifikaya sahip olabilmeleri için lisans derecesi yeterli olurken, lise öğretmenlerinin yüksek lisanslarını tamamlamaları gerekmektedir.

Türkiye ve Japonya'da İngilizce Öğretmenliği Lisans Programlarında uygulanmakta olan alan dersleri benzerlik göstermektedir. Her iki ülkede de adaylar, diğer öğretmenlik branşlarında olduğu gibi, İngilizce Öğretmenliği Lisans Programlarında da, Genel Kültür Dersleri, Alan ve Alan Eğitimi Dersleri ile Öğretmenlik Meslek Bilgisi Dersleri'ni alırlar. Aynı zamanda, fakültelerce belirlenen uygulama okullarında uygulama derslerini tamamlamaları gerekmektedir. Japonya'da 1 kredilik Sosyal Gönüllülük Çalışması bulunurken, Türkiye'de öğrenciler için Topluma Hizmet Dersi verilmektedir.

Japonya'da İngilizce öğretiminin niteliklerini arttırmak amacıyla, uygulanan "JET Programı" kapsamında, İngilizceyi özellikle anadili olarak konuşan kişiler üniversitelerde, şirketlerde ve okullarda kısmi zamanlı eğitmen olarak görevlendirilebilmektedir. Türkiye'de de özellikle konuşma becerilerinin kazandırılması amacıyla, öğrencilerin anadili İngilizce olan bireylerle etkileşim halinde olmaları oldukça önemlidir. Benzer uygulamanın Türkiye'de yaygınlaşması, hedef dilin aktif olarak konuşulması sureti ile daha iyi edinilmesini sağlayacaktır.

\section{TARTIŞMA VE SONUÇ}

Türkiye'de hem ilköğretim hem de ortaöğretim kurumları İngilizce Öğretmenliği Lisans Programları; "İlköğretim İngilizce Öğretmenliği” ve "Ortaöğretim Ingilizce Öğretmenliğĭ" şeklinde iki farklı program halinde düzenlenmelidir. İlköğretim İngilizce Öğretmenliği için öğretmen 
adaylarının, hitap edeceği öğrencilerin gelişim düzeyleri ve ihtiyaçlarına yönelik dersler verilebilir. Hali hazırda uygulanmakta olan "Çocuklara İngilizce Öğretimi” gibi çocuklara yönelik derslerin programda ağırlık kazanması, öğretmen adaylarının mesleğe atıldıklarında yaşayabilecekleri sıkıntıları azaltacaktır. Ortaöğretim İngilizce Öğretmenliği Programlarında ise, "İleri Okuma, Yazma", "Konuşma ve Dinleme" Derslerine ağırlık verilmelidir.

Öğretmen adaylarının Türkiye'de sadece sınavla seçilmesi yeterli değildir. Merkezi sınav uygulamasının yanı sıra, öğretmen adayları mülakata tabi tutulmalıdır. Adaylara, sadece Genel Kültür ve Öğretmenlik Alan Bilgisi konularını içeren testlerin yöneltildiği Kamu Personeli Seçme Sınavı'nda Alan Bilgisi soruları da yer almalıdır.

\section{KAYNAKLAR}

Adigüzel, A. (2005). “Avrupa Birliğine Uyum Sürecinde Öğretmen Niteliklerinde Yeni Bir Boyut: Bilgi Okur Yazarlı̆̆ı”. Milli Eğitim Dergisi. Yaz 2005, Y11:33, say1:167. [Online]: http://yayim.meb.gov.tr/dergiler/167/index3-adiguzel.htm adresinden 19 Temmuz 2009 tarihinde indirilmiştir.

Anadolu Üniversitesi Açıköğretim Fakültesi (2009a). Ingilizce Öğretmenliği Lisans Programı Hakkında. [Online]: http://iolp.anadolu.edu.tr/ adresinden 28 Ağustos 2009 tarihinde indirilmiştir.

Anadolu Üniversitesi Aç1köğretim Fakültesi (2009b). E Ĕitim-Öğretim. [Online]: http://iolp.anadolu.edu.tr/egitim.htm adresinden 28 Ağustos 2009 tarihinde indirilmiştir.

Aoyama Gakuin Üniversitesi Eğitim Fakültesi. (2010a). College of Education, Psychology and Human Studies. Retrieved on 06-May-2010, at

URL:

http://www.aoyama.ac.jp/en/academic/education/education.html.

Aoyama Gakuin Üniversitesi. (2010b). The Aoyama Standard. Retrieved on 06-May-2010, at URL: http://www.aoyama.ac.jp/en/academic/standard/index.html.

Asalığlu, İ. (2010). Tezsiz yüksek lisans kaldırıld formasyona 9 kriter geldi. Zaman Online, 23 Ocak 2010. [Online]: http://www.zaman.com.tr/haber.do?haberno $=943676 \&$ title=tezsizyuksek-lisans-kaldirildi-formasyona-9-kriter-geldi adresinden 06 Ağustos 2010 tarihinde indirilmiştir.

Atakan, B. (2010). Formasyon için ögrencilere kolaylık. Milliyet, 23 Ocak 2010. [Online]: http://www.milliyet.com.tr/formasyon-icin-ogrencilere- 
kolaylik/guncel/haberdetayarsiv/14.08.2010/1189607/default.htm adresinden 06 A ğustos 2010 tarihinde indirilmiştir.

Avrupa Birliği ve Kültür Genel Müdürlüğü (ABKGM). (2001) Eğitim Sistemlerinin Gelecekteki Somut Hedefleri. Komisyon Raporu. Brüksel Ankara: $\mathrm{AB}$ ve Kültür Genel Müdürlüğü. [Online]: http://projeler.meb.gov.tr adresinden 17 Ocak 2009 tarihinde indirilmiştir.

Balay, R. (2004). Küreselleşme, Bilgi Toplumu ve Eğitim. Ankara Üniversitesi Ĕgitim Bilimleri Fakültesi Dergisi. 37(2), 61-82.

Can, A. (2005). Ingilizce Öğretmeni Yetiştirme Programının Kazandırdiğ Konu Alanı Öğretmen Yeterliklerinin Standartlara Göre Değerlendirilmesi. Yayınlanmamış Doktora Tezi, Ankara Üniversitesi Eğitim Bilimleri Enstitüsü, Ankara.

Coşkun, H. (2009). "Türkiye ve Almanya'da Yabancı Dil Öğretmeni Yetiştirme Programlarının Karşılaştııılması”. C.Ü. Sosyal Bilimler Dergisi. Mayıs 2009. Cilt:33, No:1, 61-73.

Council of Local Authorities for International Relations (2009). The Japan Exchange and Teaching Programme (JET) 2009-2010 English Programme Pamphlet. Retrieved on 13-June-2009, at URL: http://www.jetprogramme.org/documents/pubs/2009_Pamphlet_e.pdf.

Erdoğan, İ. (2003). Karşılaştırmalı Eğitim: Türk Eğitim Bilimleri Çalışmaları İçinde Önemsenmesi Gereken Bir Alan. Gazi Üniversitesi Türk Ĕgitim Bilimleri Dergisi, Say1 3, Cilt 1. [Online]: http://www.tebd.gazi.edu.tr/c1s3.html adresinden 03 Şubat 2010 tarihinde indirilmiştir.

Gömleksiz, M. N. (1999). Yabancı Dil Öğretiminde Modüler Öğretim Yöntemi ile Geleneksel Yöntemin Öğrenci Başarısı Üzerine Etkisinin Karşılaştırllması (F.Ü. Teknik Ĕgitim Fakültesi Örneği). Yayınlanmamış Doktora Tezi, Fırat Üniversitesi Sosyal Bilimler Enstitüsü, Elazı̆̆.

Güler, G. (2005). Avrupa Konseyi Ortak Dil Kriterleri Çerçeve Programı ve Türkiye'de Yabancı Dil Öğretim Süreçleri. Trakya Üniversitesi Sosyal Bilimler Dergisi, Cilt:6 Say1.1 Haziran 2005, 89-106.

Iwate Üniversitesi (2010). University Outline. Retrieved on 26-January2010, at URL: http://www.iwate-u.ac.jp/english/outline/index.html.

Karasar, N. (2008). Bilimsel Araştırma Yöntemi (17.Baskı). Ankara: Nobel Yayın Dă̆ıtım.

Kitao, S.K, Kitao,K., Nozawa,K., Masayo, Y. (1994). Teaching English in Japan. Retrieved on 07-April-2010, at URL: Web: http://www1.doshisha.ac.jp/ kkitao/library/article/tejk.htm. 
Lauwerys, J. A., Varış, F., Neff, K. (1971). Mukayeseli Eğitim. Ankara: A.Ü. Eğitim Fakültesi.

Mantero,M., Iwai, Y. (2005). Reframing English Language Education in Japan. Asian EFL Journal, Volume 7, Issue 2, June 2005, Article 10.

MEB [Milli Eğitim Bakanlığı]. (2009a). Ingilizce Öğretmeni Yetiştirme Projesi.

[Online]:

http://oyegm.meb.gov.tr/ogr_yet/ingilizce_ogrt_yet_proj.htm

adresinden 28 A ğustos 2009 tarihinde indirilmiştir.

MEB [Milli Eğitim Bakanlığı]. (2009b). Millî Ĕgitim Bakanlı̆̆ına Bağll Ĕgitim Kurumlarına Ögretmen Olarak Atanacakların Atamalarına Esas Olan Alanlar İle Mezun Oldukları Yüksek Öğretim Programları Ve Aylık Karşılı̆̆ Okutacakları Derslere İlişkin Esaslar. Tebliğler Dergisi, Sayı:2617. [Online]: http://mevzuat.meb.gov.tr/html/2513 0.html adresinden 28 Ağustos 2009 tarihinde indirilmiştir.

Meriç, G., Tezcan, R. (2005). Fen Bilgisi Öğretmeni Yetiştirme Programlarının Örnek Ülkeler Kapsamında Değerlendirilmesi (Türkiye, Japonya, Amerika ve İngiltere Örnekleri). Balıkesir Üniversitesi Fen Bilimleri Enstitüsü Dergisi (2005).7.1, 72.

Milliyet. (2010). MEB öğretmen açı̆̆ı sayısını açıkladı. Milliyet Gazetesi, 21 Haziran 2010. [Online]: http://www.milliyet.com.tr/ siyaset/ son dakika.aspx $?$ aType $=$ SonDakika\&ArticleID $=1253432 \&$ Date $=22.06 .201$ $0 \&$ Kategori $=$ siyaset $\& b=$ MEB $\% 20$ ogretmen $\% 20$ acigi $\% 20$ sayisini $\% 20 a$ cikladi adresinden 06 Ağustos 2010 tarihinde indirilmiştir.

ÖSYM [Öğrenci Seçme ve Yerleştirme Merkezi]. (2010) Öğrenci Seçme ve Yerleştirme Sistemi (ÖSYS) Kılavuzu. Ankara: Öğrenci Seçme ve Yerleştirme Merkezi. [Online]: http://www.osym.gov.tr/ Genel/ dg.ashx?DIL=1\&BELGEANAH=35386\&DOSYAISIM=2010_OSYS BASVURU_KLVZ.pdf adresinden 11 May1s 2010 tarihinde indirilmiştir.

Sağlam, M., Kürüm, D. (2005). Türkiye ve Avrupa Birliği Ülkelerinde Öğretmen Eğitiminde Yapısal Düzenlemeler ve Öğretmen Adaylarının Seçimi. Milli Eğitim Dergisi, Y11 33, Say1 167. [Online]: http://yayim.meb.gov.tr/dergiler/167/index3-kurum.htm adresinden 15 Temmuz 2009 tarihinde indirilmiştir.

Shishin, A. (2002). The Problems of Xenophobia and the Teaching of English at Japanese Universities. Erfurt Electronic Studies in English [EESE]. EESE 7/2002. Retrieved on 04-August-2009, at URL: Web: http://webdoc.gwdg.de/edoc/ia/eese/artic22/shishin/7_2002.html.

Simmons, M. (2010). Teaching English in Japan. Retrieved on 04-May2010, at URL: Web: http://www.eslemployment.com/articles/ teachingenglish-in-japan 365.html. 
Tok, H., Arıbaş, S. (2008). Avrupa Birliğine Uyum Sürecinde Yabancı Dil Öğretimi. İnönü Üniversitesi Eğitim Fakültesi Dergisi Cilt:9, Sayı:15, Bahar 2008, 205-227.

Türker, F. (2002). Ingilizce Öğretmeni Yetişstirmede Uzaktan Ĕ̈itim. Paper presented at the international 24 Mayis 2002 Symposium on Open and Distance Education. [Online]: http://aof20.anadolu.edu.tr/program.htm adresinden 05.04.2010'da alınmıştır.

Türkoğlu, A. (1985). Fransa, İsveç ve Romanya Eğitim Sistemleri. Ankara: Ankara Üniversitesi Eğitim Bilimleri Fakültesi Basımevi.

Türkoğlu, A. (1998). Karşılaşstırmalı Ĕgitim Dünya Ülkelerinden Örneklerle. Adana: Baki Kitabevi.

Ültanır, G. (2000). Karşılaştırmalı Eğitim Bilimi Kuram ve Teknikler. Ankara: Eylül Yayınları.

Yıldız Teknik Üniversitesi. (2009). Ingilizce Öğretmenliği Sertifika Programi. [Online]: http://www.yde.yildiz.edu.tr/intro-stf.htm adresinden 28 Ağustos 2009 tarihinde indirilmiştir.

Yıldız Teknik Üniversitesi [YTÜ]. (2010). 15. Dönem İngilizce Ögretmenliği Formasyon Programı. [Online]: http://www.sem. yildiz.edu.tr/programdetay.php?progID=45 adresinden 06 Ağustos 2010 tarihinde indirilmiştir.

Yonesaka, S. (1999). The Pre-service Training of Japanese Teachers of English. The Language Teacher Online: Issue 23.11; November 1999. Retrieved on 06-May-2010, at URL: http://www.jalt-publications. org/tlt/articles/1999/11/yonesaka.

YÖK [Yükseköğretim Kurulu]. (2008). Ortä̈ğretim Alan Öğretmenliği Tezsiz Yüksek Lisans Programları. [Online]: http://www.yok. gov. tr /index.php?option $=$ com_docman\&task $=$ doc_download\&gid $=144$ adresinden 31 Ağustos.2009 tarihinde indirilmiştir.

YÖK [Yükseköğretim Kurulu]. (2009). İngilizce Öğretmenliği Lisans Programı Ders İçerikleri [Online]:http://www. yok.gov.tr/ component/ option,com_docman/task,doc_download/gid,12/Itemid,215/ adresinden 28 Ağustos 2009 tarihinde indirilmiştir. 
